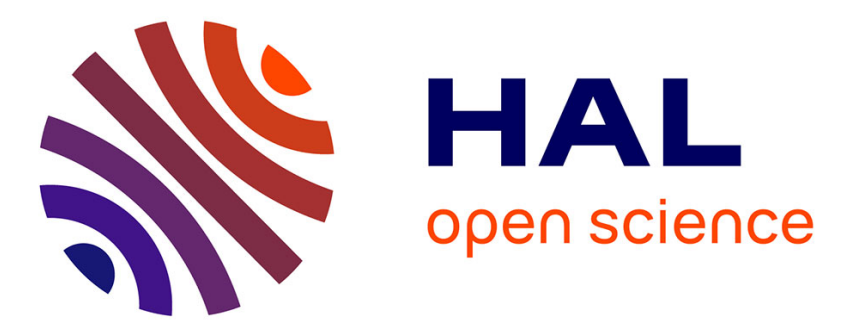

\title{
Prevalence of anti-S100A10 antibodies in antiphospholipid syndrome patients
}

\author{
V. Salle, A. Sagnier, M. Diouf, J. Schmidt, A. Smail, A. Galmiche, Y.E. \\ Herpe, P. Duhaut
}

\section{- To cite this version:}

V. Salle, A. Sagnier, M. Diouf, J. Schmidt, A. Smail, et al.. Prevalence of anti-S100A10 antibodies in antiphospholipid syndrome patients. Thrombosis Research, 2019, 179, pp.15 - 19. 10.1016/j.thromres.2019.04.027 . hal-03485724

\section{HAL Id: hal-03485724 \\ https://hal.science/hal-03485724}

Submitted on 20 Dec 2021

HAL is a multi-disciplinary open access archive for the deposit and dissemination of scientific research documents, whether they are published or not. The documents may come from teaching and research institutions in France or abroad, or from public or private research centers.
L'archive ouverte pluridisciplinaire HAL, est destinée au dépôt et à la diffusion de documents scientifiques de niveau recherche, publiés ou non, émanant des établissements d'enseignement et de recherche français ou étrangers, des laboratoires publics ou privés.

\section{(ㅇ)(1) $\$$}

Distributed under a Creative Commons Attribution - NonCommerciall 4.0 International 


\section{Prevalence of anti- S100A10 antibodies in antiphospholipid syndrome 2 patients}

$3 \quad{ }^{1,2}$ V. Salle, ${ }^{1}$ A. Sagnier, ${ }^{3}$ M. Diouf, ${ }^{1}$ J. Schmidt, ${ }^{1}$ A. Smail, ${ }^{2}$ A. Galmiche, ${ }^{4}$ YE 4 Herpe and ${ }^{1} \mathrm{P}$. Duhaut

$5 \quad{ }^{1}$ Department of Internal Medicine, Amiens University Hospital, France

$6 \quad{ }^{2}$ Laboratory of Biochemistry, Amiens University Hospital, France

$7{ }^{3}$ Division of Clinical Research and Innovation, Amiens University Hospital, 8 France

$9 \quad{ }^{4}$ Picardy Biobank, Amiens University Hospital, France

Correspondence to: Dr V. Salle, Department of Internal Medicine, Amiens University Hospital, F-80054 Amiens cedex 1, France.

Phone: +33 322668230

Fax: +33 322668239

E-mail: salle.valery@ chu-amiens.fr

Key words : antiphospholipid syndrome, S100A10, annexin A2

\section{HIGHLIGHTS}

- S100A10 is a binding partner of annexin A2

- S100A10 plays a pivotal role in regulation of fibrinolysis

- S10010 has been identified as a new autoantigen in antiphospholipid syndrome

- The prevalence of anti-S100A10 in APS patients (11.9\%) was statistically higher than in control group $(1.7 \%)$

- Further studies in large cohort of APS patients are needed to confirm these preliminary data and to determine whether these antibodies could be pathogenic 


\section{ABSTRACT}

Introduction

Annexin A2 (ANXA2), an endothelial cell receptor for plasminogen and tissue plasminogen activator, has been identified as a new autoantigen in antiphospholipid syndrome (APS). ANXA2 can exist as a monomer or a heterotetrameric complex with S100A10 protein. This S100A10 subunit also plays a pivotal role in the regulation of fibrinolysis. The aim of this study was to evaluate the prevalence of autoantibodies directed against S100A10 protein in patients with APS.

Methods. Patients with primary antiphospholipid syndrome (PAPS), patients with systemic lupus erythematosus (SLE) and patients with unexplained thrombosis were retrospectively included in this study. Patients were followed in the department of Internal Medicine of Amiens University Hospital, Amiens, France. IgG and IgM anti-S100A10 antibodies were detected in the serum of patients by enzyme-linked immunosorbent assay. The cut-off value for positivity was defined as 3 standard deviations above the mean optical density (OD) obtained in the sera of 116 healthy blood donors.

Results. The study group consisted of 116 healthy individuals and 106 patients: 42 APS patients (26 patients with PAPS and 16 patients with secondary SLE-related APS), 43 SLE patients without APS and 21 patients with unexplained thrombosis. The median age of APS patients, SLE patients without APS, patients with unexplained thrombosis and healthy individuals was 47, 38, 53 and 42 years, respectively. Anti-S100A10 antibodies were detected in $11.9 \%$ of APS patients and this prevalence was statistically higher than that observed in healthy individuals $(1.7 \%)(\mathrm{p}=0.0148)$. Highest levels of anti-S100A10 were observed in the serum of one PAPS patient with venous thrombosis and one SLE patient with APS with a history of stroke and recurrent miscarriage.

Conclusion. S100A10 protein, the binding partner of ANXA2, was identified as a target of autoantibodies in sera from patients with APS. Further studies involving a large cohort of APS patients are required to determine whether these antibodies could play a role in thrombogenic mechanisms of APS and to determine their diagnostic value in discriminating clinical subgroups of patients with APS, particularly those with seronegative APS. 


\section{INTRODUCTION}

Antiphospholipid syndrome (APS) is a systemic autoimmune disease characterized by vascular thrombosis and/or pregnancy morbidity associated with persistent antiphospholipid antibodies (1). Several pathogenic mechanisms are involved in APS, such as activation of endothelial cells, platelets and monocytes, inhibition of the natural anticoagulant protein $\mathrm{C} /$ protein S pathway, activation of the complement system and impairment of fibrinolysis (2, 3). Many components of the fibrinolytic system are targets for autoantibodies in APS, such as tissue activator plasminogen (tPA), plasminogen (Plg), plasmin and annexin A2 (ANXA2) (3). ANXA2, an endothelial cell surface receptor for tPA and Plg (4), was identified as a new autoantigen in APS by several groups several years ago (5-7). ANXA2 belongs to the family

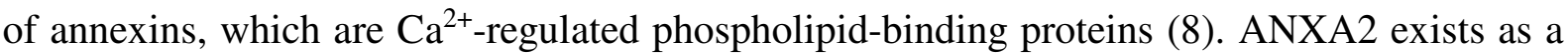
monomer in cytoplasm or can form a heterotetrameric complex associated with the cell membrane (9). This complex, comprising two ANXA2 subunits and a dimer of S100A10, is involved in the assembly of tPA and Plg at the endothelial cell surface. S100A10 promotes the translocation of ANXA2 to the cell surface (10) and ANXA2 protects S100A10 from proteasomal degradation (11). Conflicting models have been proposed concerning the exact role of these proteins (either ANXA2 or S100A10) individually (or as a complex) in the plasmin activation process (12-14). S100A10 belongs to the S100 family of small dimeric calcium-binding proteins (10-12 kD), which are involved in several cellular processes, such as cell cycle regulation, cell growth, cell differentiation, motility, contraction, secretion and transcription (15). S100 proteins contain two EF-hand motifs, which, except for S100A10, are responsible for $\mathrm{Ca}^{2+}$-binding $(16,17)$. S100A10 has been observed in various cell types, such as endothelial cells, macrophages, fibroblasts, epithelial cells and cancer cell lines (17). S100A10 binds to tPA and Plg and plays a role in regulation of plasmin generation (17). S100A10 has also been shown to play an important role in fibrinolysis and angiogenesis in vivo (18). The aim of this study was to evaluate the prevalence of anti-S100A10 autoantibodies in APS.

\section{PATIENTS AND METHODS}

Patients

Patients with systemic lupus erythematosus (SLE), primary antiphospholipid syndrome (PAPS) and unexplained thrombosis were retrospectively included in this study. All SLE patients met the revised American College of Rheumatology classification criteria (19). 
The majority of APS patients met the revised criteria for APS (1), but some patients presented clinical features of APS with low positive anticardiolipin antibodies (ACL) and the diagnosis of APS in these patients can be equivocal (20). Other patients also presented clinical features of APS, but with negative "classical" antiphospholipid antibodies corresponding to a diagnosis of seronegative APS (21). Patients with venous or arterial thrombosis with no hereditary coagulation defects constituted the unexplained thrombosis group. None of these patients had any underlying autoimmune or neoplastic disease. All patients were monitored at the Amiens University Hospital department of Internal Medicine. Healthy individuals were recruited at the Amiens branch of the French Blood Agency-North of France and from the general population. Demographic data were collected for patients and healthy individuals. APS subtypes were recorded for each APS patient, as follows: arterial, venous, microvascular, obstetric and catastrophic (according to Asherson's criteria) (22). The following laboratory data were collected for APS and SLE patients: IgG and IgM anticardiolipin antibodies (ACL), IgG and IgM anti- $\beta 2$ glycoprotein I antibodies (aB2GPI). Blood samples for patients and blood donors were stored at $-80^{\circ} \mathrm{C}$ at the Picardy Biobank. Each patient and healthy individual provided written informed consent to use these stored samples for research. Ethical review and approval were not required for this study in accordance with the local legislation and institutional requirements at the beginning of the study.

\section{Detection of anti-S100A10 antibodies}

An Enzyme-linked Immunosorbent assay (ELISA), performed in the biochemistry laboratory, was used to detect $\operatorname{IgG}$ and $\operatorname{IgM}$ anti-S100A10 antibodies. The S100A10 recombinant protein (ABNOVA, Taïwan, RDC) was used as antigen. 96-well plates were coated overnight at $+4^{\circ} \mathrm{C}$ with S100A10 recombinant protein $(0.5 \mu \mathrm{g} / \mathrm{ml})$ in even rows and with phosphate buffered saline (PBS) in odd rows. After three washes with PBS/0.1\% Tween (PBST), wells were blocked with 3\% bovine serum albumin in PBST for $90 \mathrm{~min}$ at room temperature. Wells were then washed three times with PBST and serum (diluted to 1:200 in blocking buffer) was added to both S100A10- and PBS-coated wells in duplicate for $30 \mathrm{~min}$ at room temperature. Mouse monoclonal anti-S100A10 antibody (Abcam, Cambridge, UK) was used as positive control. Sera from both patients and healthy individuals were used for each ELISA assay. After three washes with PBST, wells were incubated with $100 \mu \mathrm{L}$ of peroxidase-conjugated antibodies (goat anti-mouse IgG, goat anti-human IgG, goat antihuman IgM (Sigma, St. Louis, MO, USA)) (diluted to 1:2000 in PBST) for $30 \mathrm{~min}$ at room 
temperature. After three washes, $100 \mu \mathrm{L}$ of tetramethylbenzidine solution (Sigma) were added and color development was stopped with $50 \mu \mathrm{L}$ of $\mathrm{H}_{2} \mathrm{SO}_{4}$. Absorbance was measured at 405 $\mathrm{nm}$ and the results were expressed as optical density (OD), calculated by subtracting the background from wells without S100A10. The cutoff value for determining positivity of antiS100A10 IgG or IgM was defined by 3 standard deviations (SD) above the mean value observed with a serum panel from 116 blood donors

Statistical analysis

The prevalence of anti-S100A10 antibodies in patients and controls was compared by Fisher's exact test. 95\% confidence intervals were calculated using the exact Klopper- Pearson method. A Kruskal Wallis test was used to compare the crude level of anti-S100A10 IgG and IgM titers in healthy individuals and the groups of patients with SLE without APS, APS and unexplained thrombosis. Post hoc analyses were performed using the Wilcoxon rank-sum test with Hochberg adjustment. A pvalue $<0.05$ was considered for statistical significance.

All statistical analyses were performed with RStudio software Version 1.0.143 - (C) 2009-2016 RStudio (R.3.4.0 software).

\section{RESULTS}

\section{Patient characteristics}

One hundred six patients were retrospectively included as follows: 42 APS patients, 43 SLE patients without APS, 21 patients with unexplained thrombosis and 116 healthy individuals. Five patients had seronegative APS, one of whom had seronegative obstetric APS with positive anti-annexin A5 antibodies. Two patients had equivocal APS. Patient demographic characteristics and biological profile of antiphospholipid antibodies of APS and SLE patients are summarized in Table 1. APS patients presented a female predominance $(78.5 \%)$ and the sex ratio was almost the same as that reported in a large cohort of APS patients (23). Signs of venous thrombosis were present in the majority of APS patients and arterial thrombosis was observed in almost one-half of APS patients. Catastrophic APS was observed in 2 patients.

Prevalence of anti-S100A10 antibodies

The prevalence of anti-S100A10 antibodies among healthy individuals was 2 out of 116 patients $(1.7 \%)$ (Table 2), similar to the reported prevalence of anti-annexin A2 in healthy 
populations $(5,6)$. Anti-S100A10 antibodies were detected in almost $12 \%$ of APS patients and this prevalence was statistically higher than in the control group $(\mathrm{p}=0.0148)$ (Table 2). The prevalence of anti-S100A10 antibodies in SLE without APS was low (2.3\%) and similar to that observed in controls (Table 2). No patient had both IgM and IgG anti-S100A10. AntiS100A10 antibodies were not detected in patients with unexplained thrombosis. We found a statistically significant difference in IgG anti-S100A10 titers between the four groups studied (Fig. 1) $(\mathrm{p}=0.0002)$ and this difference was more specifically observed between unexplained thrombosis and SLE without APS ( $\mathrm{p}=0.0034)$ and between APS patients and SLE without APS $(p=0.0049)$.

The control group differed from all the other three groups regarding $\operatorname{IgG}(\mathrm{p}=0.0356, \mathrm{p}=0.0399$ and $\mathrm{p}=0.0399$ for APS, unexplained thrombosis and SLE respectively). IgG levels were not different between APS and unexplained thrombosis $(\mathrm{p}=0.7154)$. No statistically significant difference was observed when we compared APS patients with and without anti-S100A10 antibodies in terms of clinical phenotype such as venous thrombosis, arterial thrombosis, microvascular thrombosis and obstetric morbidity (data not shown). We did not find any positive results for anti-S100A10 antibodies in patients with catastrophic APS, the most severe form of APS. The highest anti-S100A10 antibody levels were observed in serum from two patients, a woman with SLE and APS with a history of thrombotic events, such as stroke and recurrent pregnancy losses, and a man with PAPS and deep vein thrombosis (Table 3).

\section{DISCUSSION}

This present study identified, for the first time, S100A10 as a target antigen for autoantibodies in APS. Anti-S100A10 antibodies were significantly more prevalent in patients with APS than in healthy individuals. S100A10 is a binding partner of ANXA2 (24) and plays an important role in fibrinolysis (18). At the cell surface, S100A10 is present predominantly in a heterotetrameric complex consisting of two ANXA2 subunits and a S100A10 homodimer (17). ANXA2 stabilizes intracellular S100A10 and endothelial translocation of ANXA2 to the cell surface requires S100A10 expression (10). The prevalence of anti-S100A10 antibodies was lower than that of anti-ANXA2 antibodies reported in APS by Cesarman-Maus (22.6\%) (5). The amino-terminal tail domain of ANXA2 contains the binding site for S100A10 and the S100A10 subunits of the heterotetrameric complex are positioned in the center of the complex in the classical "closed" conformation (25). However, three different molecular arrangements 
of the tetrameric complex are observed depending on the presence of calcium and S100A10 is exposed away from the phospholipid bilayer in the "open" conformation (25). The conformation of the tetrameric complex may therefore mask target epitopes present on S100A10 protein. Furthermore, in a recent study evaluating the vascular expression of ANXA2 and its S100A10 subunit in lupus nephritis, the vascular expression of S100A10 in patients with lupus nephritis was less intense than that observed for ANXA2 (26). However, the study involves a relatively small number of patients and further studies in a large cohort of APS patients are needed to confirm these preliminary data. Among positive patients for antiS100A10 antibodies, three APS patients were also positive for anti-ANXA2 antibodies with the same isotype (data not shown). The co-occurrence of antibodies against S100A10 and to ANXA2 could be explained by epitope spreading to distinct proteins within the same protein complex. One of the two APS- positive patients with the highest levels of anti-S100A10 antibodies was a 51-year-old female patient with SLE and APS with a history of stroke and recurrent pregnancy losses. S100A10 is present in the core transcriptome of 115 genes that are critical for placental function across species (27). In a recent study investigating the cellular localization of ANXA2/S100A10 complex, expression of S100A10, ANXA2 and the ANXA2/S100A10 complex was observed in amniotic membrane, blood vessels, the brush border area of the syncytium and trophoblasts (28). S100A10 may also play a crucial role in embryo implantation (29). In the light of these data, we hypothesize that anti-S100A10 antibodies could have a pathogenic role in patients with obstetric morbidity. Further studies are needed to determine whether anti-S100A10 antibodies are associated with obstetric morbidity. S100A10 has a widespread distribution in body tissues, particularly in the brain. An interaction has been observed between S100A10 and the serotonin receptor, 5-HT1B, and S100A10 increases the localization of 5-HT1B receptors at the cell surface (30). S100A10 knockout mice exhibit a depression-like phenotype (30). APS patients may present several psychiatric manifestations, such as depression (31). S100A10 also plays a crucial role in endothelial cell function by regulating plasmin generation. S100A10 knockout mice present increased vascular fibrin deposition. Cerebral involvement in APS involves an APL-induced "prothrombic state" and an immune-mediated pathogenesis with direct binding of APL to central nervous system antigens. Further studies are needed to evaluate whether anti-S100A10 antibodies are associated with thrombotic and non-thrombotic neurological features of APS. The prevalence of anti-S100A10 antibodies should also be evaluated in patients with cryptogenic stroke or depression. 
In conclusion, we identified S100A10 protein, the binding partner of ANXA2, as a new autoantigen in APS. Further studies involving a large cohort of APS patients are required to determine whether anti-S100A10 antibodies could play a role in thrombogenic mechanisms of APS and to determine their diagnostic value in discriminating clinical subgroups of patients with APS, particularly those with seronegative APS.

\section{Acknowledgments}

We thank Dr. Agnès Brulé and Dr. Nathalie Becquet (French Blood Agency) for providing blood samples from healthy individuals, Mrs Lucie Desjardins of the Division of Clinical Research and Innovation of Amiens University Hospital, Dr. Clément Gourguechon of the department of Internal Medicine of Amiens University Hospital and Dr Ericka Berthe of the Immunology Laboratory of Amiens University Hospital, for their participation in this study.

\section{REFERENCES}

1. Miyakis S, Lockshin MD, Atsumi T, Branch DW, Brey RL, Cervera R, Derksen RH, De Groot PG, Koike T, Meroni PL, Reber G, Shoenfeld Y, Tincani A, Vlachoyiannopoulos PG, Krilis SA. International consensus statement on an update of the classification criteria for definite antiphospholipid syndrome (APS). J Thromb Haemost. 4 (2006) 295-306, https://doi.org/10.1111/j.1538-7836.2006.01753.x

2. Schreiber K, Sciascia S, de Groot PG, Devreese K, Jacobsen S, Ruiz-Irastorza G, Salmon JE, Shoenfeld Y, Shovman O, Hunt BJ. Antiphospholipid syndrome. Nat Rev Dis Primers. 4 (2018) 17103, https://doi.org/10.1038/nrdp.2018.5

3. Krone KA, Allen KL, McCrae KR. Impaired fibrinolysis in the antiphospholipid syndrome. Curr Rheumatol Rep. 12 (2010) 53-7, https://doi.org/10.1007/s11926-009-0075-4

4. Hajjar KA, Jacovina AT, Chacko J. An endothelial cell receptor for plasminogen/tissue plasminogen activator. I. Identity with annexin II. J Biol Chem. 269 (1994) 21191-7.

5. Cesarman-Maus G, Ríos-Luna NP, Deora AB, Huang B, Villa R, Cravioto Mdel C, Alarcón-Segovia D, Sánchez-Guerrero J, Hajjar KA. Autoantibodies against the fibrinolytic receptor, annexin 2, in antiphospholipid syndrome. Blood. 107 (2006) 4375-82, https://doi.org/10.1182/blood-2005-07-2636 
6. Salle V, Mazière JC, Smail A, Cévallos R, Mazière C, Fuentes V, Tramier B, Makdassi R, Choukroun G, Vittecoq O, Goëb V, Ducroix JP. Anti-annexin II antibodies in systemic autoimmune diseases and antiphospholipid syndrome. J Clin Immunol. 28 (2008) 291-7, https://doi.org/10.1007/s10875-008-9188-1

7. Ao W, Zheng H, Chen XW, Shen Y, Yang CD. Anti-annexin II antibody is associated with thrombosis and/or pregnancy morbidity in antiphospholipid syndrome and systemic lupus erythematosus with thrombosis. Rheumatol Int. 31 (2011) 865-9, https://doi.org/10.1007/s00296-010-1379-4

8. Gerke V, Moss SE. Annexins: from structure to function. Physiol Rev. 82 (2002) 331-71, https://doi.org/10.1152/physrev.00030.2001

9. Hajjar KA. The Biology of Annexin A2: From Vascular Fibrinolysis to Innate Immunity. Trans Am Clin Climatol Assoc. 126 (2015) 144-55.

10. Deora AB, Kreitzer G, Jacovina AT, Hajjar KA. An annexin 2 phosphorylation switch mediates p11-dependent translocation of annexin 2 to the cell surface. J Biol Chem. 279 (2004) 43411-8, https://doi.org/10.1074/jbc.M408078200

11. He KL, Deora AB, Xiong H, Ling Q, Weksler BB, Niesvizky R, Hajjar KA. Endothelial cell annexin A2 regulates polyubiquitination and degradation of its binding partner S100A10/p11. J Biol Chem. 283 (2008) 19192-200, https://doi.org/10.1074/jbc.M800100200

12. Waisman DM. Annexin A2 may not play a role as a plasminogen receptor. Br J Haematol. 131 (2005) 553-4, https://doi.org/10.1111/j.1365-2141.2005.05805.x

13. Cesarman-Maus G, Hajjar KA. Annexin checks in - Response to Waisman. Br J Haematol. 131 (2005) 554-6, https://doi.org/10.1111/j.1365-2141.2005.05806.x

14. Hedhli N, Falcone DJ, Huang B, Cesarman-Maus G, Kraemer R, Zhai H, Tsirka SE, Santambrogio L, Hajjar KA. The annexin A2/S100A10 system in health and disease: emerging paradigms. J Biomed Biotechnol. 2012 (2012) 406273, http://dx.doi.org/10.1155/2012/406273

15. Marenholz I, Heizmann CW, Fritz G. S100 proteins in mouse and man: from evolution to function and pathology (including an update of the nomenclature). Biochem Biophys Res Commun. 322 (2004) 1111-22, https://doi.org/10.1016/j.bbrc.2004.07.096 
16. Liu Y, Myrvang HK, Dekker LV. Annexin A2 complexes with S100 proteins: structure, function and pharmacological manipulation. $\mathrm{Br} \mathrm{J}$ Pharmacol. 172 (2015) 1664-76, https://doi.org/10.1111/bph.12978

17. Madureira PA, O'Connell PA, Surette AP, Miller VA, Waisman DM. The biochemistry and regulation of S100A10: a multifunctional plasminogen receptor involved in oncogenesis. J Biomed Biotechnol. 2012 (2012) 353687, http://dx.doi.org/10.1155/2012/353687

18. Surette AP, Madureira PA, Phipps KD, Miller VA, Svenningsson P, Waisman DM. Regulation of fibrinolysis by S100A10 in vivo. Blood. 118 (2011) 3172-81, https://doi.org/10.1182/blood-2011-05-353482

19. Hochberg MC. Updating the American College of Rheumatology revised criteria for the classification of systemic lupus erythematosus. Arthritis Rheum. 40 (1997) 1725, https://doi.org/10.1002/art.1780400928

20. Harris EN, Pierangeli SS. 'Equivocal' antiphospholipid syndrome. J Autoimmun. 15 (2000) 81-5, https://doi.org/10.1006/jaut.2000.0419

21. Hughes GR, Khamashta MA. Seronegative antiphospholipid syndrome. Ann Rheum Dis. 62 (2003) 1127, https://doi.org/10.1136/ard.2003.006163

22. Asherson RA. The catastrophic antiphospholipid syndrome. J Rheumatol. 19 (1992) 50812.

23. Cervera R, Piette JC, Font J, Khamashta MA, Shoenfeld Y, Camps MT, Jacobsen S, Lakos G, Tincani A, Kontopoulou-Griva I, Galeazzi M, Meroni PL, Derksen RH, de root PG, Gromnica-Ihle E, Baleva M, Mosca M, Bombardieri S, Houssiau F, Gris JC, Quéré I, Hachulla E, Vasconcelos C, Roch B, Fernández-Nebro A, Boffa MC, Hughes GR, Ingelmo M; Euro-Phospholipid Project Group. Antiphospholipid syndrome: clinical and immunologic manifestations and patterns of disease expression in a cohort of 1,000 patients. Arthritis Rheum. 46 (2002) 1019-27.

24. Bharadwaj A, Bydoun M, Holloway R, Waisman D. Annexin A2 heterotetramer: structure and function. Int J Mol Sci. 14 (2013) 6259-305, https://doi.org/10.3390/ijms14036259

25. Illien F, Finet S, Lambert O, Ayala-Sanmartin J. Different molecular arrangements of the tetrameric annexin 2 modulate the size and dynamics of membrane aggregation. Biochim Biophys Acta. 1798 (2010) 1790-6, https://doi.org/10.1016/j.bbamem.2010.05.001 
26. Salle V, Cordonnier C, Schmidt J, Mazière C, Smail A, Attencourt C, Mabille MP,

317 Mazière JC, Makdassi R, Choukroun G, Diouf M, Duhaut P, Ducroix JP. Vascular expression 318 of annexin A2 in lupus nephritis. J Clin Pathol. 69 (2016) 533-6, 319 http://dx.doi.org/10.1136/jclinpath-2015-203139

320 27. Armstrong DL, McGowen MR, Weckle A, Pantham P, Caravas J, Agnew D, Benirschke 321 K, Savage-Rumbaugh S, Nevo E, Kim CJ, Wagner GP, Romero R, Wildman DE. The core 322 transcriptome of mammalian placentas and the divergence of expression with placental shape. 323 Placenta. 57 (2017) 71-78, https://doi.org/10.1016/j.placenta.2017.04.015 28. Abd El-Aleem SA, Dekker LV. Assessment of the cellular localisation of the annexin A2/S100A10 complex in human placenta. J Mol Histol. 49 (2018) 531-543, https://doi.org/10.1007/s10735-018-9791-2

29. Bissonnette L, Drissennek L, Antoine Y, Tiers L, Hirtz C, Lehmann S, Perrochia H, Bissonnette F, Kadoch IJ, Haouzi D, Hamamah S. Human S100A10 plays a crucial role in the acquisition of the endometrial receptivity phenotype. Cell Adh Migr. 10 (2016) 282-98, https://doi.org/10.1080/19336918.2015.1128623

30. Svenningsson P, Chergui K, Rachleff I, Flajolet M, Zhang X, El Yacoubi M, Vaugeois JM, Nomikos GG, Greengard P. Alterations in 5-HT1B receptor function by p11 in depression-like states. Science. 311 (2006) 77-80, https://doi.org/10.1126/science.1117571

31. Ricarte IF, Dutra LA, Abrantes FF, Toso FF, Barsottini OGP, Silva GS, de Souza AWS, Andrade D. Neurologic manifestations of antiphospholipid syndrome. Lupus. 27 (2018) 1404- 


\section{Table 1}

Demographic characteristics and biological profile of antiphospholipid antibodies of APS and SLE patients

\begin{tabular}{lccccc}
\hline & $\mathrm{n}$ & $\begin{array}{c}\text { Median age, } \\
\text { years } \\
\text { (range) }\end{array}$ & Female/Male & $\begin{array}{c}\text { Positive } \\
\text { ACL }(\%)\end{array}$ & $\begin{array}{c}\text { Positive } \\
\text { aB2GPI (\%) }\end{array}$ \\
\hline Healthy individuals & 116 & $42(18-69)$ & $61 / 55$ & - & - \\
APS & 42 & $47(17-75)$ & $33 / 9$ & 61.9 & 45.2 \\
- Primary APS & 26 & $47.5(24-75)$ & $18 / 8$ & 57.6 & 38.4 \\
- Secondary APS & 16 & $35(17-56)$ & $15 / 1$ & 68.7 & 56.2 \\
related to SLE & & & & & 10 \\
SLE without APS & 43 & $38(19-78)$ & $42 / 1$ & 22.5 & - \\
$\begin{array}{l}\text { Thrombosis of } \\
\text { unknown etiology }\end{array}$ & 21 & $53(32-74)$ & $13 / 8$ & - & \\
\hline
\end{tabular}

Table 2

Prevalence of anti-S100 antibodies

\begin{tabular}{lllll}
\hline & \multicolumn{1}{c}{$\begin{array}{c}\text { APS patients } \\
(\mathrm{n}=42)\end{array}$} & $\begin{array}{l}\text { SLE patients } \\
\text { without APS } \\
(\mathrm{n}=43)\end{array}$ & $\begin{array}{c}\text { Unexplained } \\
\text { thrombosis } \\
(\mathrm{n}=21)\end{array}$ & $\begin{array}{c}\text { Controls } \\
(\mathrm{n}=116)\end{array}$ \\
\hline Positive anti-S100A10 IgG & $\begin{array}{l}1 / 42=2.4 \% \\
{[0.06 \% ; 12.6 \%]}\end{array}$ & $\begin{array}{l}0 / 43=0 \% \\
{[0 \% ; 8.2 \%]}\end{array}$ & $\begin{array}{l}0 / 21=0 \% \\
{[0 \% ; 16.1 \%]}\end{array}$ & $\begin{array}{l}1 / 116=0.9 \% \\
{[0.02 \% ; 4.7 \%]}\end{array}$ \\
\hline Positive anti-S100A10 IgM & $4 / 42=0 \%$ & $1 / 43=2.3 \%$ & $0 / 21=0 \%$ & $1 / 116=0.9 \%$ \\
& {$[0 \% ; 8.2 \%]$} & {$[0.06 \% ; 12.3 \%]$} & {$[0 \% ; 16.1 \%]$} & {$[0.02 \% ; 4.7 \%]$} \\
\hline $\begin{array}{lllll}\text { Positive anti-S100A10 IgG } \\
\text { and/or IgM }\end{array}$ & $5 / 42=11.9 \%$ & $1 / 43=2.3 \%$ & $0 / 21=0 \%$ & $1 / 116=1.7 \%$ \\
& {$[4.0 \% ; 25.6 \%]$} & {$[0.06 \% ; 12.3 \%]$} & {$[0 \% ; 16.1 \%]$} & {$[0.2 \% ; 6.1 \%]$} \\
\hline
\end{tabular}


Table 3

Clinical and Laboratory data of healthy individuals and patients with positive anti-S100A10 antibodies

\begin{tabular}{|c|c|c|c|c|c|c|}
\hline & Gender & $\begin{array}{l}\text { Age } \\
\text { (years) }\end{array}$ & Clinical manifestations & LA & ACL & aB2GPI \\
\hline Healthy* & $\mathrm{F}$ & 20 & Any & Negative & Negative & Negative \\
\hline Healthy & M & 50 & Any & Negative & Negative & Negative \\
\hline SLE & $\mathrm{F}$ & 48 & $\begin{array}{l}\text { Discoid lupus, Raynaud's } \\
\text { phenomena, serositis }\end{array}$ & NA & Positive & Positive \\
\hline PAPS & $\mathrm{F}$ & 31 & $\begin{array}{l}\text { Deep vein thrombosis, } \\
\text { pulmonary embolism }\end{array}$ & Positive & Positive & Positive \\
\hline PAPS $^{* *}$ & $\mathrm{~F}$ & 36 & $\begin{array}{l}\text { Pulmonary embolism, recurrent } \\
\text { pregnancy losses, retinal } \\
\text { ischemia }\end{array}$ & Negative & Negative & Negative \\
\hline PAPS $*$ & $\mathrm{H}$ & 68 & Deep vein thrombosis & Positive & Negative & Negative \\
\hline SLE + APS & $\mathrm{F}$ & 28 & $\begin{array}{l}\text { Superior vena cava thrombosis, } \\
\text { ischemic colitis }\end{array}$ & Negative & Positive & Positive \\
\hline $\mathrm{SLE}+\mathrm{APS}^{*}$ & $\mathrm{~F}$ & 51 & $\begin{array}{l}\text { Stroke, recurrent pregnancy } \\
\text { losses }\end{array}$ & Positive & Positive & Positive \\
\hline
\end{tabular}

* Patients with highest levels of anti-S100A10 antibodies. ${ }^{* *}$ Seronegative APS. LA: lupus available. 
A

IgG anti-S100A10

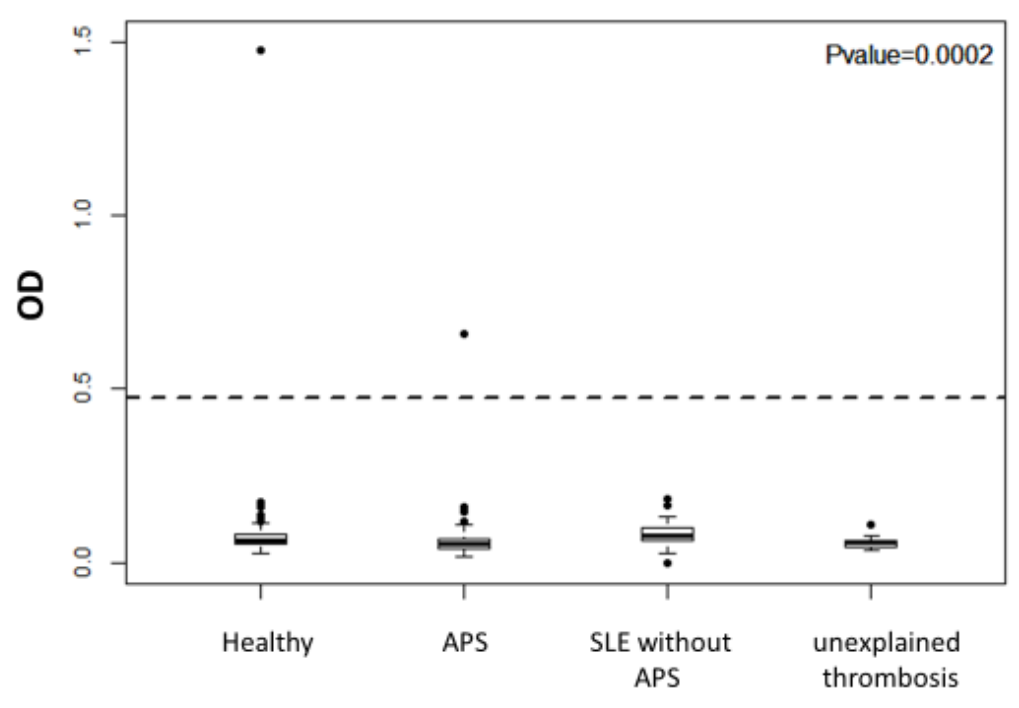

370

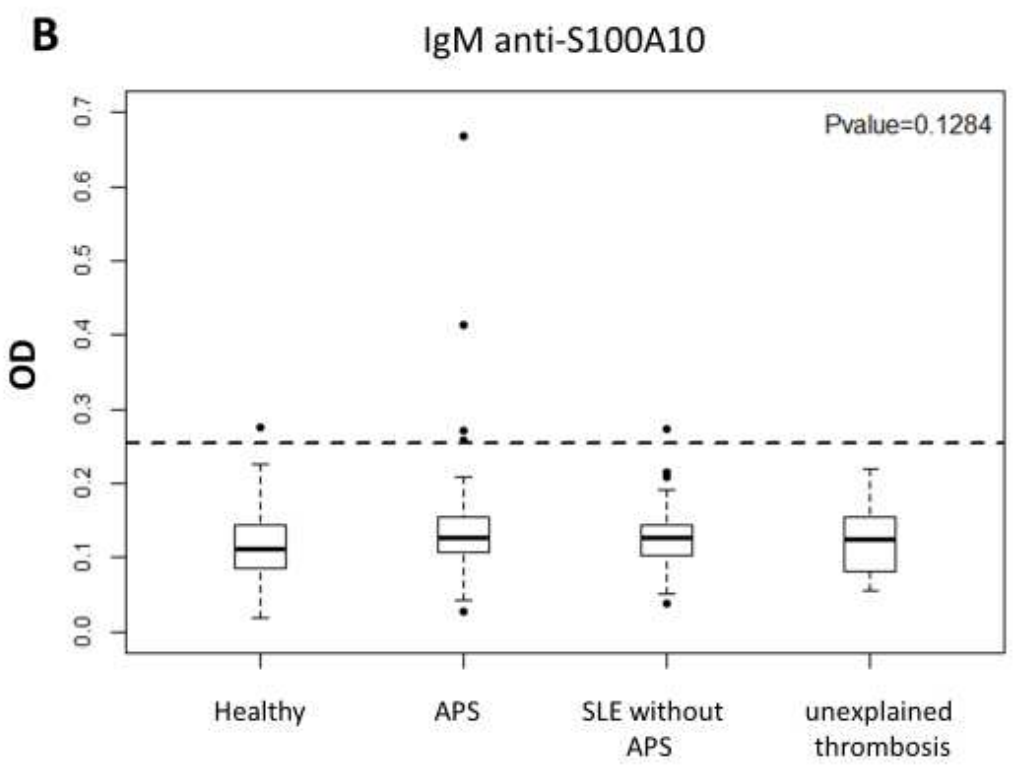

371

372 Figure 1. Levels of $\operatorname{IgG}(\mathrm{A})$ and $\operatorname{IgM}(\mathrm{B})$ anti-S100A10 antibodies in patients and controls.

373 The dashed line represents the cutoff, which is the mean OD + three standard deviations of 374 the 116 normal controls. 